\title{
Hermenêutica e exegese com o método semio-discursivo: uma análise da perícope de Êxodo 3.7-12
}

\begin{abstract}
Com o passar dos anos, muitas metodologias foram desenvolvidas para que a mensagem dos textos sagrados seja entendida em sua plenitude. No decorrer da história da interpretação bíblica, pode-se dividir em dois grandes períodos: a hermenêutica antes da reforma protestante e a hermenêutica após a reforma. Nos dias atuais, dentre as metodologias mais utilizadas a exegese Histórico-Critica é a mais utilizada pelos teólogos liberais, por sua vez, o método Histórico-Gramatical, usado vastamente na teologia reformada também encontra muito espaço e tem muito destaque. Entretanto, com uma abordagem focada na linguística da enunciação e, por consequência, nas teorias semióticas atreladas a ela, o método semio-discursivo tem ganhado muito espaço na academia e, também, tanto entre os mais ortodoxos, que creem na inerrância e na inspiração das escrituras, quanto os mais liberais, que desmitificam muito dos textos. Utilizando essa metodologia, uma das passagens mais conhecidas da Torá e, por consequência, do cânon cristão é o chamamento de Moisés para libertar o povo hebreu da situação de escravo no Egito. Portanto, seguindo esse critério, a realidade daquele povo é analisada e compreendida de acordo com diversas perspectivas diferentes. A exegese semio-discursiva enfatiza, em sua última fase, cinco ciclos da dimensão da ação: dimensão espaço-temporal, dimensão teológica, dimensão sociocultural, dimensão psicossocial e a dimensão missional. Sendo, essa última, a responsável pela aplicação das dimensões anteriores no contexto atual.
\end{abstract}

Palavras-chave: Teologia; Hermenêutica; Exegese; Método Semio-Discursivo; Êxodo.

\section{Hermeneutics and exegesis with semio-discursive method: analysis of Exodus 3.7-12 pericope}

\begin{abstract}
Over the years, many methodologies have been developed so that the message of the sacred scriptures is understood in its fullness. Throughout the history of biblical interpretation, it is possible divide into two great periods: hermeneutics before the Protestant Reformation and hermeneutics after reformation. Nowadays, among the most used methodologies, Historical-Critical exegesis is the most used by liberal theologians; in turn, the Historical-Grammatical method, widely used in Reformed theology, also finds a lot of space and has a lot of emphasis. However, with an approach focused on the linguistics of enunciation and, consequently, on the semiotic theories attached to it, the semiodiscursive method has earned much space in the academy, and also among the more orthodox, who believe in inerrancy and inspiration of the scriptures, as well as the more liberal, which demystify much of the texts. Using this methodology, one of the best-known passages of the Torah and consequently of the Christian canon is Moses' call to free the Hebrew people from the slave situation in Egypt. Therefore, following this criterion, the reality of that people is analyzed and understood according to different perspectives. Semio-discursive exegesis emphasizes in its last phase five cycles of the dimension of action: space-time dimension, theological dimension, socio-cultural dimension, psychosocial dimension and the missional dimension. Being the latter, responsible for applying the previous dimensions in the current context.
\end{abstract}

Keywords: Theology; Hermeneutics; Exegesis; Semio-Discursive Method; Exodus.

\section{Topic: Tradições e Escrituras Sagradas}

Reviewed anonymously in the process of blind peer.

Enock Fernandes Alves

Centro de Ensino Superior de Maringá, Brasil

http://lattes.cnpq.br/2570263624775114

enockmeca@yahoo.com.br

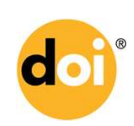

DOI: 10.6008/SPC2595-430X.2017.001.0003
Received: 06/09/2017

Approved: 09/10/2017
Referencing this:

ALVES, E. F.. Hermenêutica e exegese com o método semio-discursivo: uma análise da perícope de Êxodo 3.7-12. Social Evolution, v.1, n.1, p.27-43, 2017. DOI: http://doi.org/10.6008/SPC2595430X.2017.001.0003 


\section{INTRODUÇÃO}

A hermenêutica, conforme definida por Zabatiero (2016, p. 172) tem como objetivo primário e fundamental a compreensão dos textos bíblicos dentro do seu próprio contexto e, em última análise, a aplicação do mesmo para o contexto do leitor. Leitor esse que pode viver em qualquer época, visto que os preceitos ensinados nas sagradas escrituras permeiam questões morais e éticas, sobre preservação da vida, contemporâneas de qualquer sociedade.

Desde o início do século presente, vive-se num período o que, claramente, há uma transição nas teorias e práticas hermenêuticas, especialmente no campo da interpretação bíblica. Zabatiero (2016) diz que estamos saindo de um período o qual as ciências históricas e, mais ainda, a da sociologia, predominaram como referenciais teóricos para a exegese, em contraponto a um novo período no qual as ciências da linguagem estão se tornando o referencial teórico principal nessas abordagens. A linguística da enunciação e, por consequência, as teorias semióticas e discursivas a ela vinculadas, traz uma interessante possibilidade para a hermenêutica bíblica: ela faz com que o exegeta continue no caminho traçado na história da interpretação bíblica que já tem, pelo menos, mais de dois mil anos, ao passo que o leitor não fica vinculado a uma única forma de ler a Bíblia.

O entendimento das Sagradas Escrituras, bem como sua correta aplicação, traz consequências para a sociedade como um todo. Sendo o Brasil um país de hegemonia cristã, a maneira como se interpreta um texto canônico pode, de certa forma, influenciar as atitudes daqueles que creem e praticam os preceitos. Sendo que, essa influência, pode ocorrer de maneira positiva ou negativa.

A perícope em estudo é vastamente conhecida pelas culturas judaicas e, também, pelos cristãos católicos e protestantes. Esse trabalho traz como novidade a aplicação de uma metodologia relativamente nova e ainda pouco desenvolvida. A aplicação do método semio-discursivo a esse texto não foi encontrada em lugar algum logo, indubitavelmente, uma perspectiva diferenciada será desvendada.

Em suma, o relato fala da teofania vivida por Moisés e do seu chamamento para libertar seu povo. Povo esse que vivia como escravos debaixo do julgo do rei do Egito, a saber, o homem considerado como um deus para os egípcios, o faraó.

\section{METODOLOGIA}

O método Semio-Discursivo, conforme descrito por Zabatiero (2016), é dividido em três fases, a saber, preliminar, preparatória e final, que, passo a passo, vai se tornando mais complexo e abrangente. Cada fase tem seus objetivos e, basicamente, o seu desenrolar é feito através de uma série de perguntas que são levantadas ao texto. Cada uma dessas fases alimenta a outra e retroalimenta a anterior. Então, pouco a pouco, a exegese do texto vai sendo construída até culminar a fase final, sendo ela a mais importante e complexa. Esta etapa, por sua vez, é estruturada em cinco ciclos, ou seja, o mesmo texto é estudado e analisado de cinco pontos de vista diferentes, todos baseados na teoria semio-discursiva. 


\section{Fase Preliminar}

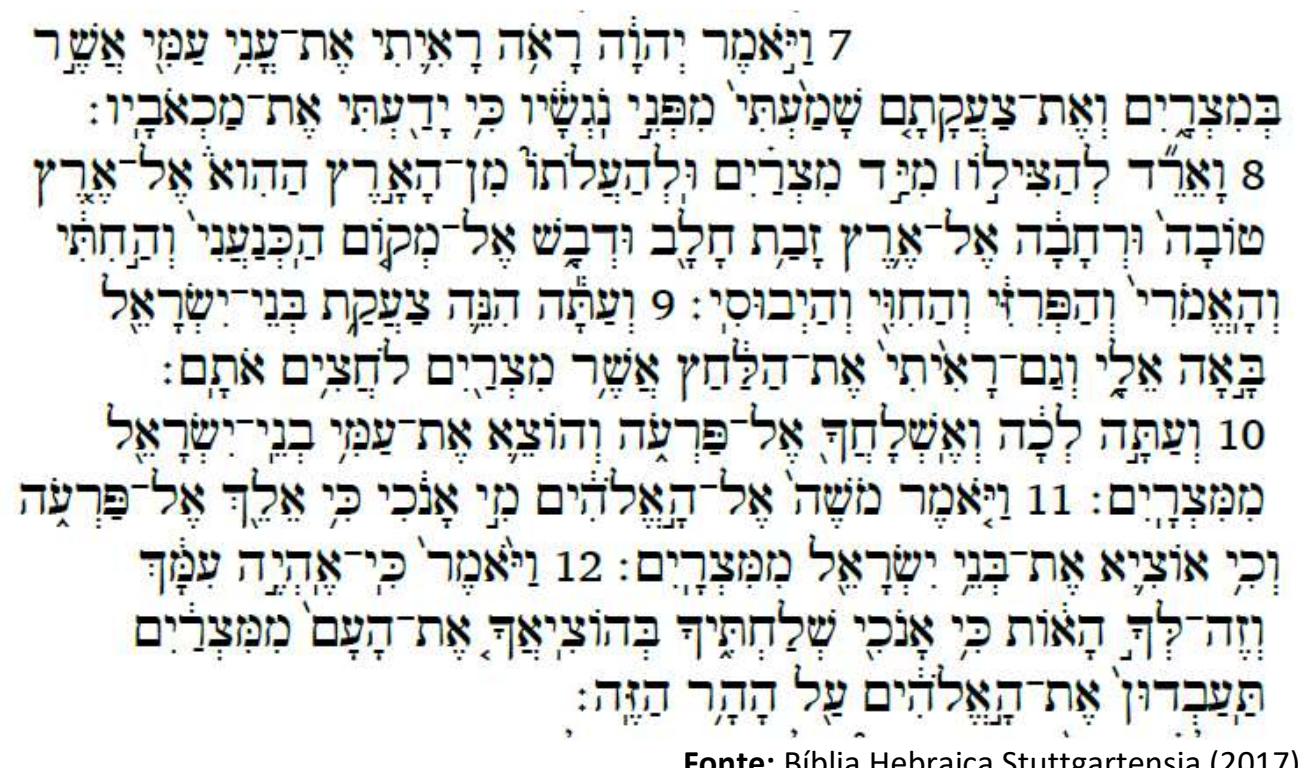

\section{Tradução:}

Disse o Senhor: "De fato tenho visto a opressão sobre o meu povo no Egito, e também tenho escutado o seu clamor, por causa dos seus feitores, e sei quanto eles estão sofrendo.

Por isso desci para livrá-lo das mãos dos egípcios e tirá-los daqui para uma terra boa e vasta, onde manam leite e mel: a terra dos cananeus, dos hititas, dos amorreus, dos ferezeus, dos heveus e dos jebuseus.

Pois agora o clamor dos israelitas chegou a mim, e tenho visto como os egípcios os oprimem. Vá, pois, agora; eu o envio ao faraó para tirar do Egito o meu povo, os israelitas".

Moisés, porém, respondeu a Deus: "Quem sou eu para apresentar-me ao faraó e tirar os israelitas do Egito? "

Deus afirmou: "Eu estarei com você. Esta é a prova de que sou eu quem o envia: quando você tirar o povo do Egito, vocês prestarão culto a Deus neste monte".

Êxodo 3:7-12 (Tradução da Bíblia Nova Versão Internacional)

De acordo com Fuchs (2003, p. 46) o Pentateuco era muito comprido para caber em um único rolo de livro da Antiguidade, a partir daí a subdivisão em cinco rolos foi feita. Essa divisão foi realizada, entretanto, de acordo com a com o conteúdo dos textos. Os títulos dos cinco livros diferem da tradição judaica, a qual os nomeia de acordo com suas palavras iniciais hebraicas, dos títulos usados nas tradições das traduções gregas e latinas, que intentam denotar o conteúdo de cada livro.

Para Mears (2007, p. 45), em seu livro "Estudo Panorâmico da Bíblia", a grande temática e ponto fundamental do livro de Êxodo é a apresentação de Jesus Cristo como nosso cordeiro Pascal. Para ela, nos capítulos doze a dezenove, temos "uma história emocionante da Páscoa, a figura mais clara da salvação individual pela fé no AT, no sangue vertido por nosso Senhor Jesus Cristo". É justamente nessa narrativa que se extrai o subsídio para nomear Jesus o "Cordeiro de Deus, Cristo nossa Páscoa", dentre outras referências à crucificação e morte do nosso Cordeiro Pascal. "Pois Cristo, nosso Cordeiro pascal, foi sacrificado" (BíBLIA, 1 Co 5:7b). 
Mears (2007, p.45) ainda complementa que, num panorama geral, enquanto o livro de Gênesis aponta para o fracasso do homem em todas as provas e condições, é no livro do Êxodo que é descrita a epopeia emocionante de Deus vindo para socorrer o homem. Ou seja, é o livro preeminentemente redentor do antigo testamento.

Martinho Lutero (2017, p.97-98) em seu comentário bíblico do livro do Êxodo diz:

[...] quando o mundo já estava cheio [de gente] e mergulhado na cegueira, de sorte que quase já não se sabia o que era pecado ou onde teria vindo a morte, Deus suscita Moisés com a lei, tomando um povo particular com a finalidade de nele novamente iluminar o mundo e, de novo, revelar, através da lei, o pecado.

Ele ainda reitera que aqueles homens veterotestamentários que entendem a intenção da lei e que as suas exigências são impossíveis, se afastam de todas as obras e atrevimento e aprendem com a lei, apenas, que são pecadores e que devem ansiar o Cristo. Sendo este, portanto, o ministério de Moisés, como a própria constituição da lei.

A perícope que o excerto está incluído relata que Moisés ainda morava com seu sogro, Jetro, quando teve sua primeira teofania. Relembrando a história de Moisés, ele nasceu durante os terríveis anos em que os egípcios decretaram que os bebês hebreus, do sexo masculino, fossem mortos ao nascer. Contudo, seus pais o esconderam em casa e depois, o colocaram no meio da vegetação, na margem do Nilo, num cesto de junco. A filha do Faraó descobriu a criança no cesto e essa descoberta foi providencial para que o menino sobrevivesse. Sua mãe adotiva lhe disse "eu o tirei das águas", daí veio o significado do seu nome (BÍBLIA, Ex. 1 e 2$)$.

Outra figura importante na história foi o sacerdote de Midiã, chamado Jetro. Seu nome em hebraico significa "excelência" (Gardner 2005, p. 344) e, sem dúvida, essa foi uma das características desse homem. Moisés após fugir do Egito, ajudou as sete filhas de Jetro a dar água a seus rebanhos e, por consequência, ele tornou-se amigo da família e casou-se com Zípora, uma das sete irmãs. Gardner (2005) afirma que Jetro era (ou tornou-se) um sacerdote de YHWH, uma vez que, num ato de gratidão, no qual muitos hebreus estavam presentes, Jetro ofereceu sacrifício e tanto Arão quanto os demais líderes do povo comeram pão com ele. Dentre os atos de Jetro, destaca-se a preocupação que ele teve com seu genro no tocante a sobrecarga de trabalho para atender todo o povo de Israel. O mais valioso e sábio conselho dado a Moisés foi o de estabelecer uma liderança compartilhada, a qual outros líderes capazes estariam julgando as pequenas causas e apenas entre o povo e, apenas as causas mais graves, seriam levadas para Moisés.

Nessa primeira teofania descrita por Moisés, a escritura nos relata que "O Anjo do Senhor" apareceu a ele. Segundo Gardner (2005, p.54), o “Anjo do Senhor" é mencionado mais de sessenta vezes na Bíblia e é o porta-voz pessoal de Deus e seu representante diante da humanidade. É percebido que, em algumas ocasiões, esse anjo é identificado com o próprio Deus, enquanto, em outras passagens, o anjo é diferenciado do Senhor. Em suma, Gardner acredita que o anjo do Senhor é bastante ativo no Antigo e no Novo Testamento, sempre com o intuito de realizar propósitos divinos, tanto em bênçãos quanto em maldições. É o mensageiro divino e responsável pela realização do juízo de Deus. 
Ao falar do sofrimento do povo, Deus cita que tem visto como os egípcios oprimem os hebreus (BÍBLIA, Ex 3.9). Segundo Davis (1984, p. 174), a população dos egípcios era maior na antiguidade do que nos tempos modernos, podendo chegar a quase sete milhões e meio de habitantes. Logo o povo de Israel era uma minoria reprimida e sofredora naquela nação.

O termo Faraó significava "a grande casa" (Gardner, 2005) e esta nomenclatura ficou amplamente conhecida e utilizada como título para o rei do Egito. Na cosmovisão do Antigo Egito, o Faraó tinha o status de deus, logo quando YHWH diz para Moisés que livraria o povo das mãos de Faraó, a ideia era que YHWH era mais poderoso que os outros deuses, isso porque apesar de, na revelação progressiva de YHWH, Ele ensinar ao seu povo que não existem outros deuses, naquele período, o povo hebreu era monolátrico, ou seja, cria na existência de outros deuses, contudo prestava culto apenas a YHWH. Logo, o que o leitor do século XXI precisa entender é que a missão dada a Moisés não era a missão para enfrentar um homem-rei, mas um deus-rei.

Além de enfrentar um deus, YHWH afirma que vai levar seu povo para uma terra boa e, naquelas terras, eles encontrarão alguns povos que já habitavam lá (BÍBLIA, Ex 3.8). Os Cananeus eram os habitantes de Canaã, descendentes de Cão e de outras famílias e tribos que se agregaram (Davis, 1984). Canaã e sua descendência foram amaldiçoados por Noé após a prática de um tipo de pecado sexual que envolveu o pai embriagado e o seu filho Cão (Gardner, 2005). Ou seja, os israelitas enfrentariam esse povo amaldiçoado ao chegar à terra prometida.

Os hititas (ou heteus) era um povo temido em toda região. Davis (1984, p. 273) afirma que eles eram uma raça forte, que raspavam a barba, usavam chapéus de forma cônica e túnicas largas. Os seus sapatos tinham bico arrebitados, presos com tirar à roda dos artelhos.

Outro povo cananeu que habitavam aquelas terras foram os amorreus. Davis $(1984$, p. 33) ressalta que eles "eram perversos e dados à pilhagem e à destruição". Portanto, o destaque a esse povo deve-se ao fato dos hebreus, possivelmente, temê-los ao saber que eles estariam no destino almejado.

Os fereseus eram povos aborígenes que já habitavam Canaã muito antes dos demais povos (Davis, 1984). Por morar lá há muito tempo, era de se esperar uma grande resistência para que eles deixassem as terras. Durante a conquista de Canaã pelos hebreus eles não foram exterminados e, posteriormente, levaram o povo de Israel à idolatria.

Dentre os povos que ocupavam Canaã, vale ressaltar a presença dos heveus: conforme lembra Davis (1984, p. 274), os heveus não foram derrotados, pois alcançaram por meio de um estratagema, um tratado de paz com Josué. Após a descoberta da fraude, foi-lhes poupada à vida, mas Josué os empregou a serrar madeira e carregar água.

Por fim, os Jebuseus eram os habitantes de Jerusalém (ou Jebus). Após a conquista, eles habitaram como estrangeiros nas tribos de Judá e de Benjamim (Davis, 1984).

Um dos principais lugares que passam a perícope, e, em especial, nos versículos em destaque é o Monte Horebe (ou Monte de Deus). Esse monte também é conhecido como Monte Sinai. A narrativa não informa se esse nome foi dado posteriormente a teofania ou se já era um local conhecido desta maneira. $O$ 
fato de Moisés ir apascentar as ovelhas no Monte de Deus (se esse já fora o nome anterior) pode-se supor que Moisés ainda se lembrava do seu criador e, consequentemente, do seu povo que ainda sofria no Egito.

Por fim, o destino dos hebreus era a "terra que mana leite e mel", ou seja, Canaã. A Bíblia de Estudo da Reforma (2017, p.7), descreve que o termo "que mana leite e mel" é usado constantemente no AT abrangendo agricultura e pecuária, ou seja, descreve a Terra Prometida como tendo abundância de todas as boas qualidades da terra. Contudo, pode-se destacar a boa localização geográfica de Canaã no tocante a vantagens comerciais e de proteção natural (mar e montanhas).

Ainda nos versículos cinco e seis, percebe-se uma peculiaridade de YHWH: Ele é santo e o local que Ele está também se torna santo. Ou seja, YHWH exige do seu servo que busque a santidade. Outra característica de YHWH é sua fidelidade, a qual é lembrada no verso subsequente quando faz menção a promessa feita a Abraão. Quanto aos assuntos abordados no excerto, alguns cabem uma atenção especial. Primeiramente, já no versículo sete, YHWH se mostra preocupado com seu povo e com o sofrimento que eles estão passando. No verso oito, fica claro que o problema do povo de YHWH é o problema de YHWH, uma vez que o próprio desceu para resolver a situação e dar fim ao sofrimento. Percebe-se que, assim como descrito na criação no livro de Gênesis, Deus trabalha em conjunto e a obra do livramento também é feita em koynonia com Moisés, uma vez que ele é quem se apresentará ao Faraó. Por fim, Deus garante que estará com Moisés e com o seu povo durante essa empreitada tão difícil.

Por fim, existem algumas teorias a respeito da data de escrita do livro: segundo a Bíblia de Estudo da Reforma (2017), ao basear-se em genealogias, crônicas e relatos bíblicos, o êxodo ocorreu em abril de 1446 a.C.. Entretanto, alguns estudiosos críticos colocam essa data em dúvida, argumentando a inconfiabilidade das Escrituras e utilizando argumentos arqueológicos, apontando para uma conquista da Terra Prometida por volta de 1240 a.C..

Segundo a Bíblia de Estudo Pentecostal (1995), há também discordância entre os eruditos bíblicos conservadores e liberais, no tocante à autoria mosaica do livro de Êxodo. Ela afirma que alguns intérpretes modernos consideram o livro como uma obra conjunta, compilada por vários escritores e completada num momento muito posterior a morte de Moisés. Entretanto, na tradição judaica, desde os tempos de Josué, como também do testemunho de Jesus, do cristianismo primitivo, e dos eruditos conservadores contemporâneos, todos eles creditam ao próprio Moisés a autoria do livro.

\section{Fase Preparatória: Contexto}

O início do livro de êxodo é fortemente marcado pelo pela caracterização das sociedades que vivam no Antigo Oriente próximo. Dentre as principais características atribuídas, também, ao Egito, Zabatiero (2017, p.40) destaca:

(a) o politeísmo e a longa tradição religiosa oficial dos Estados, bem como os conflitos entre as religiões oficiais dos impérios e das cidades-estado e as religiões populares; (b) a organização tributária dos Estados, mediante a qual a corte (e seu exército) e o sistema religioso oficial (Templos e sacerdócio) eram sustentados pelos tributos recolhidos junto aos camponeses (agricultores e/ou pastores), pelos espólios de guerra, e pelo trabalho gratuito prestado pelas populações camponesas e pelos escravos de guerra ao Estado 
(corveia); (c) uma relativa miscigenação étnica-racial, provocada pelos constantes contatos interpopulacionais, não só de natureza comercial e pacífica - imagina-se, por exemplo, os efeitos de uma invasão militar com seus inevitáveis estupros, deslocamentos populacionais e mortalidade de homens jovens.

Dentro do contexto descrito por Zabatiero (2017, p. 47), no mundo do AT, a sociedade do Antigo Oriente (incluindo o Egito), eram organizadas de acordo com o que se convencionou "Modo de Produção Tributário". Nesse tipo de organização social, pode-se dividir a sociedade, basicamente, em dois grupos, a saber, a corte e o povo. Grosso modo, o "rei" cobra tributos de agricultores e pecuaristas para o sustento da corte (incluindo o aparato religioso e militar) e demanda trabalho gratuito da população (corveia). Com o apoio da aristocracia urbana, a corte controlava o comércio exterior, a religião (que não se separava do estado, ao contrário, legitimava o governo) e mantinha o exército que servia para proteger e para conquistar novos territórios, além de funções semelhantes a polícia atualmente.

Ao sair do Egito, Moisés se depara com as sete filhas Jetro. E tornando-se um novo membro da família, o texto dá a entender que eles vivam como clãs agrários, que eram uma sociedade que, segundo Zabatiero (2017, p. 49) era a alternativa de vida em contraposição ao "Modo de Produção Tributária". Esses grupos sociais resistentes se organizavam em associações de clãs ou famílias, a que se chamavam de tribos, as quais a economia e poder eram, praticamente, igualitárias. Era comum eles viverem ao lado às margens de territórios que viviam sob a dominação por grandes países ou por grandes cidades-estados.

Outro ponto relevante, já mencionado na fase preliminar, é que, no momento do chamado de Moisés para libertar o povo, YHWH o desafia a enfrentar Faraó (vers. 10) para libertar o povo. Cabe, nesse momento, relembrar que toda a civilização hebreia era monolátrica, ou seja, criam em diversos deuses, contudo, só prestava culto a um único Deus. Ou seja, como na cultura egípcia, cultura essa que Moisés conhecia muito bem desde a infância, o Faraó era o próprio deus, logo, ao ir enfrentar o Faraó, Moisés enfrentaria uma divindade. Em adição, ao citar os povos que eles enfrentariam para conquistar Canaã (vers. 8), Moisés também sabia que eles eram perversos e em maior número. $\mathrm{O}$ que, indubitavelmente, causaria certo medo e aumentaria ainda mais o desafio desta empreitada.

Havia ainda um agravante na vida de Moisés. Ele, provavelmente, já havia conhecido a história dos patriarcas Abraão, Isaque e Jacó e, também, dos livramentos e provações que eles viveram. Contudo, ao ver o sofrimento do povo e tudo o que os egípcios os faziam passarem por tanto tempo, sem sequer ver um sinal da mão poderosa de Deus agindo, é de se esperar que a fé de Moisés estivesse um pouco abalada. Daí o motivo de YHWH trazer à lembrança do incrédulo a promessa que havia feito aos patriarcas.

\section{Delimitação}

Fazendo uma análise crítica, de acordo com Zabatiero (2016), temos a delimitação da perícope quando há mudança de pessoa, tempo, espaço, vocabulário ou forma literária (gênero textual). Na verdade, apenas uma mudança não caracteriza a mudança de perícope, contudo a partir de três dos cinco fatores acima, caracteriza o término. Seguindo esses critérios, tanto a Bíblia de Estudo Pentecostal (1995), quanto a 
Bíblia de Estudo da Reforma (2017) e a Bíblia Sagrada NVT (2016), consideram que o início da perícope darse-á no início do capítulo três e vai até o final do mesmo.

Portanto, em relação à perícope anterior, há alteração de lugar (os acontecimentos acontecem no Egito), mudança de pessoas (Moisés e o Anjo do Senhor passam a fazer parte da cena) e tempo ("E apascentava Moisés..."), o que já caracteriza bem a mudança de perícope. De modo semelhante, na perícope posterior, a mudança no gênero textual, no tempo (a conversa passa a ser no futuro) e temática, uma vez que o tema central da conversa são os poderes outorgados a Moisés.

\section{Segmentação e Estruturação}

Analisando o excerto proveniente da perícope já delimitada no item anterior, podemos separar do ponto de vista de gênero textual é típico de profecia pré-exílica e comumente chamado de "oráculo de juízo", formado, principalmente, de duas partes: denúncia e sentença. De maneira semelhante ao texto de Isaías 1.21-26, Zabatiero (2017, p. 121) afirma que devido à presença do acréscimo da restauração da dignidade do povo, pode-se chamar de "oráculo de juízo com anúncio de restauração".

Já a estruturação pode ser dividida em: (a) Preocupação de YHWH com seu povo (v. 7 e 9); (b) YHWH não é um ente passivo (v. 8a); (c) Início do desafio (v. 8b e 10); (d) Moisés teme o desafio (v. 11); (e) YHWH garante que estará com Moisés (v. 12).

A estrutura geral do excerto extraído da perícope é estruturada de forma quiástica concêntrica:

A v. 7-10 Disse o Senhor

B v.11 Réplica de Moisés

A' v.12 Tréplica de YHWH

Já no primeiro segmento, percebe-se que é estruturado quiasticamente, com a promessa ocupando o centro:

A v.7 YHWH ouve o clamor

B v.8 YHWH desce para livrar

A' v.9 O clamor do povo chegou a YHWH.

No segundo segmento, temos um paralelismo sinonímico:

v. 10 Moisés e Faraó

v. 12 YHWH e Faraó

\section{A perícope no livro de Êxodo}

Numa visão panorâmica do Êxodo, temos, logo no seu início, a descrição do sofrimento manifestado através da escravidão, opressão e infanticídio dos descendentes de Jacó no Egito. É dentro desse cenário hostil que Moisés tem sua vida poupada e é criado pela filha do Faraó no palácio do rei. Devido a algumas intempéries da vida, Moisés foge e vai morar em Midiã. É nesse momento que a grande virada começa na vida dos hebreus e é, justamente, onde nossa perícope é situada. Mas especificamente, na primeira teofania 
vivida por Moisés que YHWH traz a memória que Ele é o Deus de Abraão, Isaque e Jacó e, também, promete livrar o povo do sofrimento levando-os para a Terra Prometida.

Todo o restante do livro conta a respeito da consequência de Moisés ter aceitado o desafio de YHWH e de como Deus retoma Israel como seu povo jamais esquecido. É no desenrolar da história, que Deus traz juízo sobre Faraó através das pragas e, por fim, a páscoa é instituída e o sacrifício do cordeiro já tipifica ao Cristo que está por vir (Mears, 2006). Durante os quarenta anos no deserto, YHWH tem uma das maiores manifestações da graça divina: a entrega do decálogo em Êxodo capítulo 20. Ao se preparar para deixar de ser um aglomerado de pessoas e começar a se organizar como nação, YHWH entrega algumas leis civis e cerimoniais (inclusive os detalhes dos tabernáculos) para reger essa teocracia. É no decorrer dessa jornada que o povo se mostra rebelde e mostra sua desconfiança à YHWH.

De maneira semelhante a Abraão, o fato de Moisés jamais, efetivamente, tomar posse da Terra, mostra o caráter liminar entre da vida entre a fidelidade a Deus e a infidelidade praticada pelos seres humanos (Zabatiero, 2017). Os conceitos de bênção (promessa) e maldição (não entrada na terra) são particularmente abordados nesse e nos livros que seguem a peregrinação.

\section{Fase Final: A dimensão espaço-temporal da ação}

As pessoas envolvidas no trecho extraído da perícope são YHWH (através do Anjo do Senhor), no versículo 7 [Disse o Senhor...], o discurso continua pelos versos oito, nove e dez, encerrando no verso doze.

Moisés inicia sua participação num excerto anterior ao analisado: ainda no verso 1 [Moisés pastoreava o rebanho de seu sogro...], e continua na cena até o fim do capítulo três. Ele é atraído pela teofania e segue seu diálogo com YHWH.

Povo de YHWH, no verso 7 [...tenho visto a opressão sobre o meu povo...] e no verso 8 [...desci para livrá-los...]. YHWH é o grande protagonista da cena. É Ele quem chama Moisés, relembra da Aliança com Abraão, mostra que se importa com o povo hebreu e promete livramento das aflições.

Egípcios, citados nos versos 7 [...por causa dos seus feitores...], no verso 8 [... para livrá-los das mãos dos egípcios...] e no verso 9 [... tenho visto como os egípcios os oprimem...]. Os egípcios são os grandes opressores do povo de YHWH.

Faraó, apenas no verso 9 [... eu o envio ao Faraó para tirar do Egito o meu povo...]. O grande responsável pelas atitudes do povo egípcio para com os hebreus. Ele é quem precisava ser vencido/convencido para libertação do povo.

Povos habitantes de Canaã, a saber, cananeus, os hititas, os amorreus, os ferezeus, os heveus e os jebuseus, no verso 8 somente [... a terra dos cananeus, dos hititas, dos amorreus, dos ferezeus, dos heveus e dos jebuseus.]. Os povos que viviam nesta terra eram bárbaros e violentos, ou seja, um grande desafio a ser conquistado para que alcançasse a Terra Prometida.

Os lugares mencionados na perícope são: O monte de Deus (Monte Horebe), presente no início da descrição do ambiente, já no verso 1 [... levou o rebanho para o outro lado do deserto e chegou a Horebe, o monte de Deus.]. 
O Egito, local da habitação primeira do povo e, consequentemente, o local do sofrimento, presente no verso 7 [... tenho visto a opressão do meu povo no Egito...], e é de onde o povo deve sair, verso 10 [... para tirar do Egito meu povo...] e no verso 11 [... tirar os israelitas do Egito...].

O último lugar descrito é Canaã, a Terra Prometida, que é dita como um lugar que "mana leite e mel", contudo é uma terra perigosa devido ao fato de ser habitada por povos violentos, verso 8 [... tirá-los daqui para uma terra boa e vasta, onde manam leite e mel: a terra dos cananeus, dos hititas, dos amorreus, dos ferezeus, dos heveus e dos jebuseus.].

Desta forma, a perícope se constrói na teofania (e fala) de YHWH a Moisés e na réplica que ele faz para Deus. Esse evento ocorre no Monte Horebe. Não é informado se esse era o nome do monte antes ou depois da Teofania, contudo, caso isso fosse verdade, Moisés havia escolhido o melhor lugar para apascentar as ovelhas do sogro, pois estaria "na presença de Deus" mesmo nas suas atividades diárias.

No ponto de vista temporal, o texto se constrói, em grande parte no pretérito perfeito, indicando uma ação já ocorrida e encerrada. Contudo, nas falas de YHWH, enfatiza-se o presente do indicativo, dando a conotação eterna do Senhor. Ainda no discurso de YHWH as ações que serão descritas posteriormente estão no futuro, o que traz o leitor (ainda desconhecedor do restante do texto e do desenrolar da história) um ar de suspense e desafio para o que haveria de acontecer.

Ao analisar como estão organizadas as ações e relações no tempo e no espaço, concluímos que:

(a) Moisés sai para apascentar o rebanho do seu sogro, Jetro, no Monte Horebe, ou seja, monte de Deus. (b) YHWH aparece a Moisés através de uma teofania, a saber, uma sarça ardendo em chamas que não era consumida pelo fogo; (c) Moisés se aproxima da sarça e o Senhor se identifica a ele; (d) YHWH relembra a promessa feita a Abraão e diz que tem visto o sofrimento do povo e desceu para livrá-los (e) nesse momento, é deixado claro que a atuação salvífica de YHWH será feita através de Moisés indo enfrentar Faraó, os egípcios e, ao chegar à Terra Prometida, outros povos também precisariam ser conquistados.

Quanto à organização temporal, percebem-se no texto começa contando os fatos no passado, entretanto, faz-se uma pausa para o presente no momento das falas de YHWH e de Moisés, trazendo certa dinamicidade, clareza na informação e, ainda, aproxima o leitor do sentimento de Moisés ao ter a teofania.

O texto evoca um dos mais importantes, quiçá o mais relevante, evento na história dos hebreus. Já no início do capítulo três, YHWH aparece pra Moisés e relembra a sua relação com o patriarca Abraão. Ao fazer isso, é a promessa feita a ele que está sendo trazida a lembrança. Certamente Moisés conhecia essa promessa e sabia muito quem estava falando. No desenrolar do diálogo, YHWH se apresenta como alguém muito mais poderoso do que os deuses dos egípcios e muito mais forte do que as nações que ocupavam a terra de Canaã. É de se esperar que Moisés tenha medo e duvide da sua própria capacidade, uma vez que o povo vem sofrendo já há muito tempo e, aparentemente, até aquele momento, YHWH não tem feito nada para acabar com o sofrimento do povo. O Senhor encerra o diálogo reafirmando Sua onipotência e garantindo o livramento do Seu povo. 


\section{A dimensão teológica da ação}

Sabe-se que a tradição oral foi predominante em grande parte da antiguidade e, muito provavelmente, foi através dessa maneira que Moisés passou a conhecer a história do seu povo. Dentre a origem mais embrionária da nação de Israel, o chamado daquele habitante de Harã, para constituir o povo escolhido de Deus, era algo conhecido de todos os hebreus.

Foi através, também, de uma teofania que YHWH se apresentou a Abrão e deu como promessa a seus descendentes, a posse da terra de Canaã. Ou seja, ao aparecer como uma sarça em chamas para Moisés, o Senhor estava se fazendo lembrar como Deus presente, um Deus pessoal, da mesma forma que fora com Abraão e afirma que chegou o tempo de cumprir aquela promessa:

1 Então YHWH disse a Abrão: Deixa tua terra, tua terra natal e a casa de teu pai em direção à terra que te mostrarei. 2 Consequentemente, farei de ti um grande povo e te abençoarei e honrarei o teu nome. Torna-te bênção! 3 Abençoarei os que te abençoarem e amaldiçoarei o que te desonrar; em ti serão benditos todos os clãs agrários. 4 Então, partiu Abrão conforme lhe dissera YHWH - com ele seguiu Ló. Abrão tinha setenta e cinco anos quando saiu de Harã. 5 Abrão levou Sarai, sua mulher; Ló, filho de seu irmão, todos os bens que haviam adquirido, bem como os servos que adquiriu em Harã. E começaram a jornada para a terra de Canaã. E chegaram à terra de Canaã. 6 Abrão atravessou a terra até a região de Siquém, até ao carvalho de Moré. Naquela época os cananeus habitavam na terra. 7 YHWH apareceu a Abrão e Ihe disse: à tua descendência darei esta terra. Ali edificou um altar a YHWH, pois a ele aparecera. 8 Partiu dali para a montanha a leste de Betel e armou sua tenda, com Betel a oeste e Ai ao leste. Edificou um altar a YHWH e lá invocou o nome de YHWH. (BÍBLIA, Gn 12.1-8, traduzido por Zabatiero)

No verso 6, ao afirmar que também é o Deus de Isaque, Moisés relembra que esse patriarca também teve a sua experiência pessoal com Deus e a promessa feita à Abraão era ratificada por YHWH:

Houve fome naquela terra, como tinha acontecido no tempo de Abraão. Por isso Isaque foi para Gerar, onde Abimeleque era o rei dos filisteus. O Senhor apareceu a Isaque e disse: "Não desça ao Egito; procure estabelecer-se na terra que eu lhe indicar. Permaneça nesta terra mais um pouco, e eu estarei com você e o abençoarei. Porque a você e a seus descendentes darei todas estas terras e confirmarei o juramento que fiz a seu pai Abraão. Tornarei seus descendentes tão numerosos como as estrelas do céu e lhes darei todas estas terras; e por meio da sua descendência todos os povos da terra serão abençoados, porque Abraão me obedeceu e guardou meus preceitos, meus mandamentos, meus decretos e minhas leis. Assim Isaque ficou em Gerar. (Gênesis 26:1-6, Nova Versão Internacional)

Por fim, ao lembrar-se de Jacó, YHWH está fazendo alusão à promessa feita a ele no momento em que Jacó temia descer ao Egito. Ora, Jacó sabia que, anteriormente, num mesmo momento de dificuldade, Deus havia dito para seu pai Isaque não descer ao Egito, mas permanecer onde estava. Logo, para que Jacó fosse ao Egito com sua família, o Senhor disse que ele poderia ir e, o mais importante, diz que Ele mesmo o traria de volta:

E Deus falou a Israel por meio de uma visão noturna: "Jacó! Jacó! " "Eis-me aqui", respondeu ele. "Eu sou Deus, o Deus de seu pai", disse ele. "Não tenha medo de descer ao Egito, porque lá farei de você uma grande nação. Eu mesmo descerei ao Egito com você e certamente o trarei de volta. E a mão de José fechará os seus olhos. (Gênesis 46:2-4, Nova Versão Internacional)

Certamente, a promessa feita a Jacó tinha duplo cumprimento: o primeiro com relação à morte do próprio Jacó e que seu filho José fecharia seus olhos, trazendo para ser enterrado naquele lugar. E, como pai e representante da nação, YHWH também estava prometendo que sua descendência iria sair do Egito. 
Então, antes de chamar Moisés para essa empreitada, Deus relembra que Ele prometeu a Terra para Abraão e Isaque, e prometeu que tiraria o povo do Egito à Israel.

Ao analisar as relações intertextuais e interdiscursivas, podemos chegar a algumas conclusões interessantes: YHWH ao chamar Moisés e desafiá-lo a maior prova da sua vida até aquele momento, Ele o fez lembrando as promessas já feitas para os grandes patriarcas Abraão, Isaque e Jacó. O discurso de Deus é para a realização de um ato extremamente difícil para Abraão, contudo, o mesmo Deus relembra da aliança feita e do cumprimento de todas elas.

Partindo, portanto, das relações interdiscursivas, conclui-se que Moisés, ao receber o chamado, também está recebendo a confirmação da promessa. Deus o vincula (Moisés), até Abraão, uma vez que diz que "Sou o Deus de seu pai, o Deus de Abraão, o Deus de Isaque, o Deus de Jacó" (BÍBLIA, Ex. 3.6).

Tanto Moisés quanto YHWH estavam cientes das promessas dos patriarcas e da ação poderosa de Deus na vida deles. Antes de chamar Moisés para o que seria uma grande manifestação da graça de Deus na vida do povo de Israel, YHWH relembra a promessa de dar ao povo a terra de Canaã feita para Abraão em Gênesis 12 e ratificada a Isaque em Gênesis 26. O Senhor lembra também da promessa feita a Jacó no tocante à saída do Egito. Portanto, todo o excerto analisado que envolve a conversa de Deus com Moisés, a libertação do povo e a chegada à Terra Prometida, gira em torno dos fatos ocorridos anteriormente e que chegaram a conhecimento do genro de Jetro através da tradição oral.

\title{
A dimensão sociocultural da ação
}

Apesar de não ter muito detalhes a respeito do modo de vida da família de Jetro, entende-se que a sua família se enquadrava no modo de via formado por clãs ou famílias agrárias. Conforme explicado anteriormente, essas famílias (ou conjunto de famílias) referiam-se a grupos que mantinham resistência ao "Modo de Produção Tributário", uma vez que eles estavam sempre à margem das grandes cidades-estados e usufruíam do comércio com elas.

Já o povo hebreu estava no Egito, sendo escravos de Faraó. A sociedade vivia pagando imposto para o rei e, por consequência, ele fornecia segurança para as pessoas. Ao viver como escravos, os direitos como cidadãos eram-Ihes retirados. Segundo o trecho da poesia da baiana Cledineia relata a importância dos escravos para as construções nas grandes civilizações:

\author{
Desde o início dos tempos \\ Que existiu a escravidão \\ O império Romano ergueu \\ Sua grande nação \\ Na Grécia o escravo \\ Não era considerado cidadão. \\ África também forneceu \\ Para o mundo uma porção \\ Os negros foram vendidos \\ América e tantas outras nação \\ Pra servir de mão de obra \\ E aumentar a produção... \\ SANTOS (2017)
}


Moisés, ao fugir do Egito, passa a viver com Jetro, sacerdote de Midiã. Ele sai de uma comunidade regida pelo rei e passa a viver conforme os clãs agrários viviam. Apesar de o patriarca ter maior responsabilidade pela família, o pagamento de tributos não existia, nem a corveia, nem uma série de imposições que existiam para manter a corte. O libertador dos hebreus se vê numa realidade completamente diferente da vivida anteriormente e conhecida, apenas, nas histórias dos seus antepassados e dos clãs que, por ventura, chegavam ao Egito. Há um antagonismo entre a vida na cidade e a vida no clã, e adaptar-se a essas diferentes culturas deve ter sido um desafio para Moisés.

A religião dos egípcios era politeísta e tinha como característica comum às cidades que eram monárquicas, o fato de ter a pessoa do rei como um representante da divindade. Apesar disso, vemos que os hebreus, através de José, já tinham a liberdade de seguir e adorar a YHWH e se valia dessa prerrogativa desde então.

Outra característica importante dentro da vivência do povo Hebreu é que se sabe que eles não eram Monoteístas (criam em apenas um Deus), mas sim monolatristas, ou seja, criam que existiam muitas divindades, porém prestavam cultos e adoração a um único Deus. Esse é o único Deus criador dos céus e da Terra.

Jetro era sacerdote de Midiã, contudo, apesar dos escritos canônicos não deixarem claro a que divindade esse homem adorava, entretanto, GARDNER $(2005$, p.344) afirma que Jetro era um sacerdote de YHWH, isso devido ao ato de gratidão o qual muitos hebreus estavam presentes, Jetro ofereceu sacrifício e depois o próprio Arão e outros líderes comeram pão com ele (Ex. 18.12).

Há uma dicotomia clara entre os modos de vida dos clãs agrários e o "Modo de Produção Tributário". Enquanto no primeiro a vida era mais justa e solidária, ao ponto de todos trabalharem para o bem comum, serem divididas de forma justa as tarefas e não haver relação de vassalagem entre as famílias, nas cidadesestados, o rei tributava a população, em troca de benefícios como segurança. Além do tributo, as pessoas tinham que trabalhar sem receber nada em troca (corveia) e, esse sistema, apenas enriquecia a corte que tinham seus luxos bancados pela plebe. Ainda nesse contexto, existiam os escravos, ausentes de direitos e trabalhando de forma desumana. Enquanto Moisés vivia em um clã agrário, o restante do povo vivia na escravidão.

Outro ponto dicotômico é que enquanto Moisés viva com Jetro, sacerdote de YHWH (?), o povo viva cercado de ídolos egípcios, os quais, sem dúvida, já começavam aos poucos a fazer parte da liturgia hebreia.

Por fim, Moisés precisou se readaptar com a cultura das famílias agrárias, uma vez que ele fugiu da corte, cercado de escravos para todo e qualquer trabalho braçal, para morar num local onde o labor dependia de todos.

\section{A dimensão psicossocial da ação}

Moisés era o filho adotivo da filha do Faraó. Por ter uma origem hebreia, era fato que o seu sentimento de pertencimento estaria, de alguma forma, ligado ao povo de Israel. Foi a partir disse sentimento de fazer parte do povo escolhido, que Moisés mata um egípcio por espancar um hebreu (Ex. 
2.12). Aparentemente, o povo, mesmo sabendo da origem de Moisés, não o percebia como um dos seus, uma vez que, ao invés de ser escravo, o menino que foi deixado nas águas, comia e bebia na mesa do rei, à custa dos impostos dos trabalhadores. Esse sentimento se torna claro quando, ao separar dois hebreus brigando, Moisés sofre ameaças (Ex. 2.14), o que culmina na sua fuga do Egito.

A Bíblia não relata que as autoridades egípcias montaram uma equipe de resgate ou qualquer coisa parecida para procurar Moisés. Pode-se supor, por exemplo, que também os egípcios não eram partidários da adoção feita pela filha do faraó, o que aumentaria a crise de identidade do sujeito, sem se sentir parte nem dos egípcios nem dos israelitas. Segundo Berlin, para Herder (2002:285):

Pertencer a uma dada comunidade, estar conectado com seus membros por laços indissolúveis e impalpáveis de linguagem comum, memória histórica, hábito, tradição e sentimento, é uma necessidade humana básica não menos natural do que comer, beber, ter segurança ou garantir a procriação.

Ao mudar-se para a família de Jetro, apesar do sentimento de pertencimento começar a surgir, ainda há laços históricos que o ligam ao seu povo de origem. Nesse novo ambiente, Moisés percebe, em detalhes, como funcionam as famílias seminômades e, também, as grandes vantagens no tocante à justiça social e repartição dos ganhos. Ele é capaz de fazer uma análise comparativa das injustiças vividas no "Modo de Produção Tributário" e, mais ainda, na vida escravocrata para aqueles que estão submetidos a esse tipo de governo. A partir desse contexto, pode-se supor o motivo das prerrogativas descritas no livro de Deuteronômio para quando Israel pedir um rei (Dt. 17.14-20): o rei não poderia adquirir muitos cavalos, nem tomar para si muitas mulheres, nem acumular para si muita prata e ouro. Ou seja, Moisés, ciente que o poder que um rei tem leva-o a querer extorquir o povo com os impostos, antevendo essa situação, já previne o povo nas características que o rei deverá ter. Em contrapartida a um rei usurário, a ordem é que:

Mandará fazer num rolo, uma cópia da lei, que está aos cuidados dos sacerdotes levitas para o seu próprio uso. Trará sempre essa cópia consigo e terá que lê-la todos os dias da sua vida, para que aprenda a temer o Senhor, o seu Deus, e a cumprir fielmente todas as palavras desta lei, e todos estes decretos. Isso fará que ele não se considere superior aos seus irmãos israelitas e a não se desvie da lei, nem para a direita, nem para a esquerda. Assim prolongará o seu reinado sobre Israel, bem como o dos seus descendentes. (Deuteronômio 17:18,19)

Ao ser chamado para libertar o povo, YHWH diz para Moisés que ele enfrentará "um deus", ou seja, o próprio Faraó; enfrentarão os egípcios, um povo numeroso e mais forte que eles, e, para a conquista da Terra Prometida, terá que vencer as nações que lá habitam (nações estas muito poderosas e perversas).

É de se esperar que Moisés estivesse com muito medo, contudo, conforme dito anteriormente, para animar a Moisés, YHWH diz que é o Deus de seu pai, Deus de Abraão, Deus de Isaque, Deus de Jacó. Em outras palavras, o Senhor conecta Moisés ao seu pai biológico, trazendo-o para dentro do povo e, coparticipante da promessa feita a seus antepassados.

Portanto, movido do amor que sentia pelo seu povo, Moisés, apesar de todo o receio que haveria de enfrentar, aceita o desafio de YHWH e segue para libertar o povo.

YHWH é um Deus apaixonado: apaixonado pelo seu povo, pela sua criação, por todos os seres humanos. É de se esperar que o Infinito não caiba numa descrição de um livro, por maior que ele seja. Há, 
entretanto, algumas características que podem ser extraídas na perícope: No verso 2, a primeira característica é que Deus é sobrenatural. As leis físicas não o limitam, nem servem para descrever logicamente a sua totalidade; no verso 5, uma característica imanente a Deus é a sua santidade. YHWH é santo e não pode (no sentido de possibilidade) ser imaculado. A antropopatia começa a ser descrita no verso 6, o qual YHWH demonstra que é um Deus que se lembra das promessas feitas a seu povo; se estende no verso 7 quando diz que viu a aflição do povo, ou seja, Deus se importa com o que vem acontecendo com eles. No verso 8 diz que é um Deus que liberta das aflições e injustiças. Por fim, no verso 12, YHWH se apresenta como um Deus presente.

Resumindo, o Deus que se importa com seu povo, não se esquece das promessas feitas, mesmo que muito antigas. Esse Deus não deixa sem resposta o clamor dos que estão sofrendo, mas escuta e Ele mesmo é quem "desce" para resolver a aflição do povo, prometendo, inclusive, que estará junto com Moisés ao enfrentar as situações mais difíceis que estarão por vir.

\section{A dimensão missional da ação}

O excerto em análise pode ser denominado "Chamados para fora". Ao reler a perícope, pode-se perceber que Deus ao se apresentar a Moisés, relembra das promessas feitas a Abraão, Isaque e Jacó. YHWH também faz questão de se apresentar como Deus do pai de Moisés, ou seja, o inclui novamente na descendência dos hebreus e, por consequência, como participante da aliança Abraâmica. YHWH o conclama a ir ao Egito libertar seu povo, uma vez que os mesmos estão sofrendo como escravos debaixo do jugo de injustiça dos egípcios. O discurso de YHWH não promete facilidades para a chegada da Terra Prometida, ao contrário, diz que ainda enfrentarão problemas gigantescos para alcançar a promessa dada a Abraão. Por fim, frente ao hesito de Moisés, o Senhor garante que estará com ele diante das dificuldades.

O primeiro exemplo que Deus nos dá é que Ele é um Deus de aliança, um Deus de promessas, que não se esquece do Seu povo. Ao relembrar a promessa feita a Abraão muitos anos antes, podemos ter a certeza que todas as promessas de Deus, tem, em Jesus, o sim (Bíblia, 2 Co. 1.20). Com isso, sabemos que as verdades apresentadas nas escrituras sagradas, se cumprirão. Em todo o cânon podemos aprender princípios a respeito da vontade de Deus para nossas vidas e, por consequência, as bênçãos que Ele tem preparado para seus filhos. De modo semelhante, podemos entender através da afirmação de YHWH que nada foge do seu controle, e que apesar das circunstâncias, muitas vezes, tentarem dizer o contrário, Ele está ciente de toda e qualquer situação que estamos passando.

YHWH sendo imensamente bom e completamente justo, precisamos ter as atitudes dEle descritas na Bíblia como exemplos para nossas vidas. Ao ver a injustiça que o povo estava sofrendo, o Senhor se compadece e desce para dar fim a esse sofrimento. É notório que em toda a Escritura, YHWH condena a injustiça social e, condena também, os governantes que deixam essas coisas acontecerem. Ao levar Moisés para a libertação dos hebreus, Deus está dando um fim a anos de sofrimento que eles estão passando. Quando o Senhor diz que Ele desceu, o sentido proeminente do texto é que, mesmo sabendo que Deus é onipresente, Ele se importa com o sofrimento das pessoas, e ao ir pessoalmente resolver, por consequência, 
dar fim ao desespero do povo, faz-nos lembrar de que toda e qualquer injustiça que aconteça conosco incomoda a Deus e, mais do que isso, que também somos, e devemos ser agentes de transformação nesse mundo, levando uma solução para os aflitos, oprimidos e aqueles que sofrem injustiças.

Outro ponto relevante é que, ao se apresentar a Moisés, YHWH não apenas deu uma ordem a ele, mas, antes de tudo, resolveu um conflito existente na vida de Moisés: conforme dito anteriormente, é possível que Moisés, por não ter vivido no meio do seu povo, mas tentar protegê-los mesmo vivendo dentro da corte, tenha passado toda a sua vida sem se sentir verdadeiramente parte do povo hebreu, nem fazendo parte dos governantes. Dificilmente Moisés estaria na linha sucessória do rei, ao contrário, seus irmãos e primos do palácio deveriam ter passado toda a infância e adolescência ratificando a origem plebeia dele. Se por um lado, não pertencia ao palácio, por outro não pertencia aos hebreus, frente a esse cenário, Moisés se viu forçado a fugir e morar com Jetro. A crise de pertencimento e, por consequência, de identidade de Moisés foi curada, através de uma palavra proferida pelo próprio YHWH, ao dizer que "Eu sou o Deus de seu pai, Deus de Abraão, Deus de Isaque, Deus de Jacó" (Bíblia, Ex. 3.6), o Senhor coloca Moisés de volta no povo de Israel e coparticipante da promessa. Dessa passagem podemos entender uma ação típica de YHWH para com toda a humanidade, a saber, chamar todos que o aceitarem (receberem) para serem feitos filhos dEle (Bíblia, Jo 1.12). Outra lição aprendida para nossas vidas é relembrada no livro de Provérbios que diz que "a morte e a vida estão no poder da língua" (Bíblia, Pv 18.21). Deus ensina seu povo a serem portadores de boas novas, e mostra que uma vida de sofrimento e crise pode ser resolvida através de uma palavra de ânimo e esperança, trazendo o outro para dentro dessa grande família que temos em Cristo.

Ao alertar Moisés que, ao chegar à Terra Prometida, enfrentariam povos perversos, há implicitamente uma mensagem repetida por Jesus para todas as gerações: "Eu lhes disse essas coisas para que em mim vocês tenham paz. Neste mundo vocês terão aflições; contudo, tenham ânimo! Eu venci o mundo" (Bíblia, Jo 16.33). Sabemos que passaremos por tribulações enquanto estivermos vivendo nesse mundo, mas apesar disso, o Senhor nos anima e diz que estará conosco sempre, até a consumação dos séculos (Bíblia, Mt 28.20).

Por fim, YHWH entende que Moisés ficou reticente devido a todos os desafios que o Senhor apresentara a ele. Contudo, Deus não o criticou, ao contrário, garantiu que estaria com ele em todo o tempo. O Soberano entende os nossos medos e aflições, Ele respeita nossa condição limitada, mas nos desafia a sairmos de nossas zonas de conforto e galgarmos degraus maiores com Ele. Não temos a garantia que tudo acontecerá da maneira que esperamos, mas temos a certeza que Ele sempre estará conosco quando enfrentarmos as nossas batalhas.

\section{CONCLUSÕES}

Em última análise, ao nomear a perícope de "chamados para fora", faz-se alusão ao sentido do termo Eclésia, ou seja, igreja no novo testamento. Uma vez que a igreja tem como missão ir para fora e sermos um pouco mais parecidos com YHWH. A perícope nos traz um pouco das características de Deus e como deveremos tentar ser iguais a Ele. Em especial, na luta contra a injustiça social, no socorro ao oprimido e 
gerando vida através de nossas palavras. YHWH nos ensina que Ele é um Deus que se importa com a maneira que nos sentimos e que, mesmo se estivermos com medo, Ele cuidará de nós e não nos abandonará.

\section{REFERÊNCIAS}

FUCHS, W.. Introdução ao Antigo Testamento. 1 ed. São Paulo: Loyola, 2003.

MEARS, H. C., Estudo Panorâmico da Bíblia. 2 ed. São Paulo: Vida, 2006.

BÍBLIA. Bíblia de Estudo NVI. São Paulo: Vida, 2003.

BÍBLIA. Bíblia de Estudo da Reforma. Barueri: Sociedade Bíblica do Brasil, 2017.

BÍBLIA. Bíblia Sagrada NVT. São Paulo: Mundo Cristão, 2016.

DAVIS, J. D.. Dicionário da Bíblia. 10 ed. Rio de Janeiro: JUERP, 1984.
GARDNER, P.. Quem é quem na Bíblia Sagrada. São Paulo: Vida, 2005.

BÍBLIA. Bíblia de Estudo Pentecostal. São Paulo: CPAD, 1995.

ZABATIERO, J. P. T.. Métodos de Estudo do Antigo

Testamento. Maringá: UniCesumar, 2017.

ZABATIERO, J. P. T.. Métodos e interpretação bíblica.

Maringá: UniCesumar, 2016.

SANTOS, C. C.. Poesias e Poemas: Escravidão, resistência e luta. Porto Alegre: PUCRS, 2017.

BERLIN, I.. Estudos sobre a humanidade: uma antologia de ensaios. São Paulo: Companhia das Letras, 2002. 